\title{
Inhibitory Effect of Lactobacillus plantarum CQPC02 Isolated from Chinese Sichuan Pickles (Paocai) on Constipation in Mice
}

\author{
Bihui Liu, ${ }^{1,2,3,4}$ Xin Yang, ${ }^{5}$ Liujin Guo, ${ }^{4}$ Jing Zhang, ${ }^{6}$ Xianrong Zhou, ${ }^{1,2,3}$ Ruokun Yi, ${ }^{1,2,3}$ \\ and Xin Zhao $\mathbb{D D}^{1,2,3}$ \\ ${ }^{1}$ Chongqing Collaborative Innovation Center for Functional Food, Chongqing University of Education, Chongqing 400067, China \\ ${ }^{2}$ Chongqing Engineering Research Center of Functional Food, Chongqing University of Education, Chongqing 400067, China \\ ${ }^{3}$ Chongqing Engineering Laboratory for Research and Development of Functional Food, Chongqing University of Education, \\ Chongqing 400067, China \\ ${ }^{4}$ College of Biological and Chemical Engineering, Chongqing University of Education, Chongqing 400067, China \\ ${ }^{5}$ Department of Pediatrics, The First Affiliated Hospital of Chengdu Medical College, Chengdu 610500, China \\ ${ }^{6}$ Environment and Quality Inspection College, Chongqing Chemical Industry Vocational College, Chongqing 401228, China
}

Correspondence should be addressed to Xin Zhao; zhaoxin@cque.edu.cn

Received 3 March 2019; Revised 1 May 2019; Accepted 8 May 2019; Published 23 May 2019

Academic Editor: Barbara Speranza

Copyright (c) 2019 Bihui Liu et al. This is an open access article distributed under the Creative Commons Attribution License, which permits unrestricted use, distribution, and reproduction in any medium, provided the original work is properly cited.

Sichuan pickles (Paocai) are a traditional Chinese fermented vegetable food that is rich in beneficial microorganisms. In this study, the inhibition of constipation by Lactobacillus plantarum CQPC02 (LP-CQPC02) isolated from Sichuan Paocai was studied by establishing a constipation model of mice using activated carbon. The constipation inhibition effect of LP-CQPC02 was determined by observing the defecation of mice, rate of active carbon propulsion, pathological section observation, serum index, and small intestinal mRNA expression. The results showed that LP-CQPC02 inhibited the decrease in body weight caused by constipation in mice. At the same time, LP-CQPC02 also increased the propulsion rate of activated carbon in the small intestine and shortened the time of discharge for the first black stool. LP-CQPC02 increased gastrin (Gas), motilin (MTL), endothelin (ET), and acetylcholinesterase (AChE) in constipated mice, and it also decreased the level of somatostatin (SS). qPCR results showed that LP-CQPC02 upregulated the expression of c-Kit, stem cell factor (SCF), and glial cell-derived neurotrophic factor (GDNF) and downregulated the expression of transient receptor potential cation channel subfamily $\mathrm{V}$ member 1 (TRPV1) and inducible nitric oxide synthase (iNOS) in mice with constipation, and a stronger effect was observed with a high concentration of LPCQPC02. The experimental results showed that LP-CQPC02 has a stronger constipation inhibitory effect than the commonly used commercial Lactobacillus delbrueckii subsp. bulgaricus (LB), and the inhibitory effect of LP-CQPC02 on constipation increases with increasing concentration of LP-CQPC02. Therefore, LP-CQPC02 is a high-quality microbial resource with a good constipation inhibition effect and probiotic potential.

\section{Introduction}

In China, Sichuan pickles (Paocai) are produced by washing fresh pickles, sealing them in jars containing brine, and allowing anaerobic fermentation to proceed [1]. Salt water plays an important role in the process of vegetable juice exudation. Lactic acid bacteria use soluble sugar and nitrogen components to proliferate themselves, produce acidic substances, and metabolize flavor components, which results in the unique sour and crisp taste of the pickles [2]. Paocai contains abundant natural lactic acid bacteria that play a key role in the formation of kimchi flavor and quality [3]. Certain lactic acid bacteria are also used as probiotics and have a variety of health benefits, including the prevention of constipation, colitis, liver damage, and diabetes [4-7]. Previous studies have elucidated the mechanism of the 
efficacy of lactobacillus, the antioxidant effect of Lactobacillus fermentans LF31 and Lactobacillus coryniformis, and the constipation prevention effect of Lactobacillus plantarum YS4 $[8,9]$. Our research team isolated and identified the microorganisms from Sichuan Paocai and conducted further study of all Lactobacillus that were present.

There are many types of pickles in East Asian countries, and an increasing number of studies have been carried out on the probiotic microorganisms in pickles. Lactic acid bacteria in pickles not only have good functional effect but also can be used to produce fermented food. With the biological activity of lactic acid, functional foods can be developed. Our team has also isolated and identified the microorganisms in pickles. In the current study, lactic acid bacteria were isolated and identified from natural fermented Sichuan Paocai in Chongqing, China.

In addition to probiotics, there are also harmful bacteria in the intestine. Normally, they are in equilibrium [10]. Probiotics in the intestine are also involved in digestion. Without probiotics, indigestion and digestive tract dysfunction will occur [11]. Lactic acid bacteria in the gastrointestinal tract can effectively inhibit the growth and reproduction of harmful bacteria through lactic acid metabolism and maintain the ecological balance and normal function of the intestinal tract. Chronic diarrhea, constipation, abdominal distension, dyspepsia, and other symptoms are related to the imbalance of lactic acid bacteria in the intestine [12]. Lactobacillus activates macrophage phagocytosis and also plays an active role in intestinal colonization. Lactobacillus can stimulate peritoneal macrophages, induce interferon, promote cell division, produce antibodies, promote cellular immunity, enhance nonspecific and specific immune response, and improve disease resistance $[13,14]$. Constipation is mainly manifested by difficulty in defecation and dry stool [15], and it can slow down intestinal peristalsis, increase harmful intestinal bacteria, and further cause other intestinal diseases [16].

As a probiotic, lactic acid bacteria have been used to alleviate constipation. Studies have also found that the correlation between lactic acid bacteria and intestinal flora regulation mainly comes from two aspects. First, lactic acid bacteria can produce organic acids in the intestine, repair and promote intestinal function, reduce the $\mathrm{pH}$ of the intestinal cavity, regulate intestinal neuromuscular activity, and enhance intestinal peristalsis, thereby promoting intestinal digestion and absorption. Second, lactic acid bacteria can effectively inhibit the growth of intestinal spoilage bacteria, improve intestinal remission, and cause feces to be soft and conducive to excretion [17].

In this study, activated carbon was used to establish an animal model of constipation, resulting in abnormal physiological effects of the small intestine and inducing constipation in mice. Our team isolated and identified Lactobacillus plantarum CQPC02 (LP-CQPC02) from Sichuan Paocai, and herein, we observed the inhibitory effect of LP-CQPC02 on experimental constipation. The mechanism of LP-CQPC02 was further elucidated through molecular biology experiments, which laid a foundation for further study.

\section{Materials and Methods}

2.1. Laboratory Strain. Our team separated Lactobacillus plantarum CQPC02 (LP-CQPC02) from Sichuan Paocai in Chongqing, China, and it was preserved (CGMCC No. 14491) at the China General Microbiological Culture Collection Center (CGMCC, Beijing, China) after identification. Lactobacillus delbrueckii subsp. bulgaricus (LB, CGMCC No. 1.16075) was obtained from the CGMCC as a comparative strain with LP-CQPC02.

2.2. Induction of Constipation in Mice. Sixty SPF-grade 6week-old female Kunming (KM) mice were purchased from the Laboratory Animal Center of Chongqing Medical University (Chongqing, China). The animals were fed in a standardized laboratory with room temperature $25 \pm 2{ }^{\circ} \mathrm{C}$, relative humidity $50 \pm 5 \%$, and $12 \mathrm{~h}$ light $/ 12 \mathrm{~h}$ darkness. The experiment began one week after adaptive feeding. Fifty mice were randomly divided into five groups after one week of adaptive feeding, with 10 mice in each group, namely, the normal group, control group, Lactobacillus delbrueckii subsp. bulgaricus gastric lavage group (LB group), Lactobacillus plantarum CQPC02 low-concentration gastric lavage group (LP-CQPC02-L), and Lactobacillus plantarum CQPC02 high-concentration gastric lavage group (LPCQPC02-H). The entire experimental period was 10 days. From the first day after a week of adaptive feeding, the normal group and control group were given normal saline every day. The LB group was given $1.0 \times 10^{9} \mathrm{CFU} / \mathrm{kg}$ of the LB strain, and the LP-CQPC02-L and LP-CQPC02-H groups received $1.0 \times 10^{8} \mathrm{CFU} / \mathrm{kg}$ and $1.0 \times 10^{9} \mathrm{CFU} / \mathrm{kg}$, respectively, of LP-CQPC02. From the 7th day to the 9th day, except for the normal mice, the mice in each group were given $0.2 \mathrm{~mL}$ per day of $10 \%$ activated carbon ice water. During the experiment, mice were weighed every day. After the 9th day of gavage, all mice were fasted for $24 \mathrm{~h}$, and on the 10th day, all mice were gavaged with $0.2 \mathrm{~mL}$ of $10 \%$ activated carbon ice water. Then, each group of mice was divided into two groups, and five mice were gavaged with activated carbon ice water to observe the time of excretion of their first black stool; the remaining five mice were euthanized after $30 \mathrm{~min}$ of gavage with activated carbon ice water, and plasma was collected. The small intestine from the pylorus to the ileocecal region was removed to measure the length of the small intestine and the propulsion distance of activated carbon in the small intestine. The propulsion rate of the small intestine was calculated by the following formula: activated carbon propulsion rate $(\%)=$ activated carbon propulsion distance $(\mathrm{cm}) /$ length of the small intestine $(\mathrm{cm})$ [18], the small intestine was from the pylorus to appendix. This study was conducted in accordance with the Declaration of Helsinki, and the protocol was approved by the Ethics Committee of Chongqing Collaborative Innovation Center for Functional Food (201807004B).

2.3. Determination of Endothelin (ET), Somatostatin (SS), Motilin (MTL), Gastrin (Gas), and Acetylcholinesterase (AChE) in Mouse Serum. Mouse blood was collected, and 
after $1 \mathrm{~h}$, the blood was centrifuged at $4500 \mathrm{r} / \mathrm{min}$ for 15 minutes. Serum levels of ET, SS, MTL, Gas, and AChE were determined using kits (Nanjing Jiancheng Bioengineering Institute, Nanjing, China).

2.4. Observation of the Small Intestine Tissue Section from Mice. The $0.5 \mathrm{~cm}^{2}$ small intestinal tissues of mice were immediately fixed in $10 \%$ formalin solution for $48 \mathrm{~h}$. After dehydration, transparency treatment, wax immersion, embedding, and sectioning, $H \& E$ staining was performed to observe the morphological changes of the small intestinal tissues under optical microscopy (BX43, Olympus, Tokyo, Japan).

2.5. Quantitative PCR ( $q P C R$ ) Assay. Total small intestinal RNA was extracted with TRIzol reagent according to the instructions (Invitrogen, Waltham, MA, USA). The purity and concentration of the total RNA were determined using an ultra-microspectrophotometer (Nano-100, All For Life Science, Hangzhou, Zhejiang, China), and then, the concentration of RNA in all samples was adjusted to the same level $(1 \mu \mathrm{g} / \mu \mathrm{L})$. Then, $1 \mu \mathrm{g} / \mu \mathrm{L}$ RNA sample was added to $1 \mu \mathrm{g} / \mu \mathrm{L}$ primer dT and $10 \mu \mathrm{L}$ sterile ultrapure water, and the mixture was reacted at $65^{\circ} \mathrm{C}$ for $5 \mathrm{~min}$. When the reaction was completed, $1 \mu \mathrm{g}$ RiboLock RNase Inhibitor, $2 \mu \mathrm{g}$ $100 \mathrm{mM}$ dNTPs, $4 \mu \mathrm{g} 5 \times$ reaction buffer, and $1 \mu \mathrm{g}$ RevertAid M-mu/RT (Thermo Fisher Scientific, Inc., Waltham, MA, USA) were added to the reaction system. The total reaction volume of $20 \mu \mathrm{g}$ liquid was homogeneously mixed, and then, it was subjected to $42^{\circ} \mathrm{C}$ for $60 \mathrm{~min}$ and $5 \mathrm{~min}$ at $70^{\circ} \mathrm{C}$, for RevertAid/RT. After gene synthesis, the target gene was retranscribed and amplified. The following reaction conditions used were: $95^{\circ} \mathrm{C}$ denaturation for $15 \mathrm{~min}, 60^{\circ} \mathrm{C}$ annealing for $1 \mathrm{~h}$, and $95^{\circ} \mathrm{C}$ extension for $15 \mathrm{~min}$, for a total of 40 cycles. The relative expression (Table 1) of the target gene was calculated by the $2^{-\Delta \Delta C t}$ method using DAPDH as a housekeeping gene [18].

2.6. Statistical Analysis. In this study, the experiments were carried out in triplicate, and the results were averaged. Then, the standard deviation was obtained from each group of data to measure the data difference from three experiments performed using the same parameters. Finally, one-way ANOVA analysis was carried out for each group of data, and a conclusion was drawn by comparing the differences $(p<0.05)$ using the SAS 9.1 statistical software [18].

\section{Results}

3.1. Body Weight Changes in Mice. Observing the weight changes in the mice, it was found that the weight of mice in each group increased normally before they induced constipation (Figure 1). The weight gain of mice in the LPCQPC02-H group decreased after induced constipation, while that of mice in the LP-CQPC02-L, LB, and control group decreased; the greatest weight loss was observed in the control group mice. Therefore, LP-CQPC02 and LB can
TABLE 1: Sequences of primers used in the qPCR assay.

\begin{tabular}{|c|c|}
\hline $\begin{array}{l}\text { Gene } \\
\text { name }\end{array}$ & Sequence \\
\hline c-Kit & $\begin{array}{l}\text { Forward: 5'-AGA CCG AAC GCA ACT T-3' } \\
\text { Reverse: } 5^{\prime} \text {-GGT GCC ATC CAC TTC A-3' }\end{array}$ \\
\hline SCF & $\begin{array}{l}\text { Forward: 5'-AAA CTG GTG GCG AAT C-3' } \\
\text { Reverse: } 5^{\prime} \text {-CAC GGG TAG CAA GAA C-3' }\end{array}$ \\
\hline GDNF & $\begin{array}{c}\text { Forward: 5'-TTT TAT TCA AGC CAC CAT C-3' } \\
\text { Reverse: } 5^{\prime} \text {-AGC CCA AAC CCA AGT CA-3' }\end{array}$ \\
\hline TRPV1 & $\begin{array}{l}\text { Forward: 5'-AGC GAG TTC AAA GAC CCA GA-3' } \\
\text { Reverse: } 5^{\prime} \text {-TTC TCC ACC AAG AGG GTC AC-3' }\end{array}$ \\
\hline iNOS & $\begin{array}{l}\text { Forward: 5'-AGA GAG ATC GGG TTC ACA-3' } \\
\text { Reverse: 5'-CAC AGA ACT GAG GGT ACA-3' }\end{array}$ \\
\hline GAPDH & $\begin{array}{l}\text { Forward: 5'-AGG TCG GTG TGA ACG GAT TTG-3' } \\
\text { Reverse: } 5^{\prime} \text {-GGG GTC GTT GAT GGC AAC A-3' }\end{array}$ \\
\hline
\end{tabular}

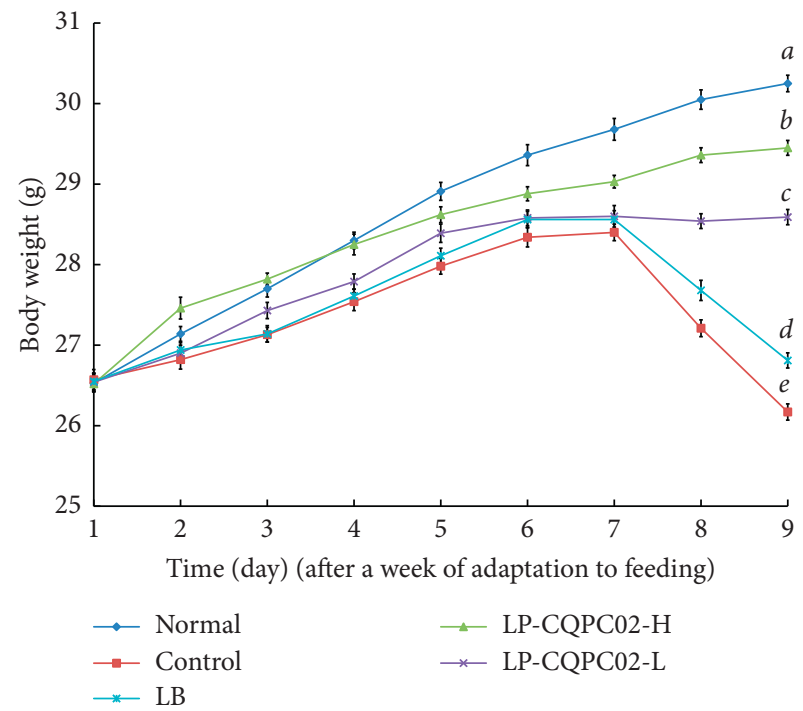

FIgURE 1: The body weight changes in the mice. Values presented are the mean \pm standard deviation. ${ }^{\mathrm{a}-\mathrm{e}}$ The mean values with different letters in the same bars are significantly different $(p<0.05)$ according to Duncan's multiple-range test; there was no significant difference in the same letter representation between the two bars $(p>0.05)$, but there was significant difference in the different letter representation $(p<0.05)$. LB: Lactobacillus delbrueckii subsp. bulgaricus $\left(1.0 \times 10^{9} \mathrm{CFU} / \mathrm{kg}\right.$ b.w. gavage); LPCQPC02-L : Lactobacillus plantarum CQPC02 $\left(1.0 \times 10^{8} \mathrm{CFU} / \mathrm{kg}\right.$ b.w. gavage); LP-CQPC02-H : Lactobacillus plantarum CQPC02 $\left(1.0 \times 10^{9} \mathrm{CFU} / \mathrm{kg}\right.$ b.w. gavage $)$.

inhibit the weight loss caused by constipation in mice, and the high concentration of LP-CQPC02 was the most optimal.

3.2. First Black Stool Discharge Time in Mice. The results showed that the first black stool discharge time was the longest in the control group and the shortest in the normal group (Figure 2). After the times for the LP-CQPC02 and LB groups were recorded, it was evident that the first black stool discharge time of constipated mice was shorter. The first black stool discharge time of constipated mice after LP- 


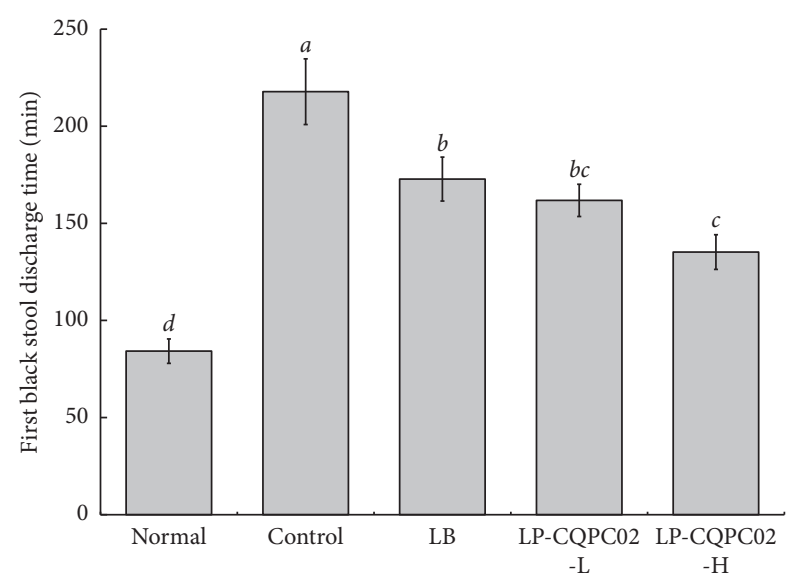

Figure 2: First black stool discharge time of the mice. The values presented are the mean \pm standard deviation. ${ }^{\mathrm{a}-\mathrm{d}}$ The mean values with different letters in the same bars are significantly different $(p<0.05)$ according to Duncan's multiple-range test; there was no significant difference in the same letter representation between the two bars $(p>0.05)$, but there was significant difference in the different letter representation $(p<0.05)$. LB:Lactobacillus delbrueckii subsp. bulgaricus $\left(1.0 \times 10^{9} \mathrm{CFU} / \mathrm{kg}\right.$ b.w. gavage); LPCQPC02-L: Lactobacillus plantarum CQPC02 $\left(1.0 \times 10^{8} \mathrm{CFU} / \mathrm{kg}\right.$ b.w. gavage); and LP-CQPC02-H:Lactobacillus plantarum CQPC02 $\left(1.0 \times 10^{9} \mathrm{CFU} / \mathrm{kg}\right.$ b.w. gavage $)$.

CQPC02-H administration was significantly $(p<0.05)$ lower than that of the LP-CQPC02-L and LB mice. It can be concluded that the defecation time of constipated mice was decreased after LP-CQPC02 treatment in a dose-dependent manner, with a decrease that corresponded to the increase in LP-CQPC02 concentration.

\subsection{Activated Carbon Propulsion Rate in the Small Intestine of} Mice. By observing the small intestine of mice, it was found that the propulsion rate of activated carbon in the small intestine of the normal mice was the highest (Table 2). The propulsion rate of activated carbon in the small intestine of the LP-CQPC02-H group was significantly $(p<0.05)$ higher than that of other groups except the normal group. At the same time, the propulsion rate of activated carbon in constipated mice treated with LP-CQPC02-L and LB was significantly $(p<0.05)$ higher than that in the control mice. This shows that LP-CQPC02 can repair the intestinal tract, promote the propulsion of activated carbon in the small intestine, and inhibit constipation.

3.4. Serum MTL, Gas, ET, SS, and AChE Levels in Mice. The serum levels of MTL, Gas, ET, and AChE in the normal mice were the highest, while the serum levels of SS were the lowest (Table 3). In the control mice, the serum levels of MTL, Gas, ET, and AChE were the lowest, while the serum levels of SS were the highest. LP-CQPC02 and LB increased the levels of MTL, Gas, ET, and AChE in the serum of mice with constipation and decreased the levels of SS. LPCQPC02-H had the strongest effect and can be used as a serum indicator of mice that are close to that of the normal mice.

3.5. Pathological Observation of the Small Intestine Tissue. Small intestinal tissue in the normal mice exhibited villi that were uniformly arranged without breaking or shrinking, while the villi of the control mice showed a great deal of breaking and shrinking, and the goblet cells were incomplete (Figure 3). Although the small intestinal villi of LB-, LPCQPC02-L-, and LP-CQPC02-H-treated mice were also contracted and fractured to a certain extent, the small intestinal morphology and villi of mice in the LF-CQPC10-H group were more complete than those of the control mice, and the small intestinal villi morphology and villi of mice in the LF-CQPC10-H group were almost the same as those of the mice in the normal group.

3.6. $c$-Kit mRNA Expression in the Small Intestine of Mice. The results of qPCR showed that the c-Kit mRNA expression in the small intestine of the normal mice was the strongest (Figure 4). The c-Kit expression intensity in the small intestine of LP-CQPC02-H mice was only lower than that of the normal mice, which was significantly $(p<0.05)$ higher than that of the other groups. The expression of $\mathrm{c}-\mathrm{Kit}$ in the small intestine of LP-CQPC02-L and LB mice was slightly higher than that of the control group, but there was no significant difference $(p>0.05)$.

3.7. SCF mRNA Expression in the Small Intestine of Mice. The normal mice showed the strongest expression of SCF, while the control mice showed the weakest expression of SCF (Figure 5). After LP-CQPC02 and LB treatment, the expression of SCF in constipated mice was upregulated, and the ability of LP-CQPC02-H to upregulate the expression of SCF was significantly $(p<0.05)$ stronger than that of LPCQPC02-L and LB.

3.8. GDNF mRNA Expression in the Small Intestine of Mice. The results showed that the expression of GDNF was weakest in the small intestine of the control group, but strongest in the normal group (Figure 6). Through the effects of LPCQPC02 and LB, the expression of GDNF in the small intestine of the constipated mice was significantly $(p<0.05)$ upregulated, and the strongest upregulation occurred in mice that received the high concentration of LP-CQPC02 (LP-CQPC02-H).

3.9. TRPV1 mRNA Expression in the Small Intestine of Mice. Compared with the normal group, the expression of TRPV1 in the small intestine of the control group was significantly $(p<0.05)$ upregulated after induced constipation (Figure 7$)$. LP-CQPC02 and LB inhibited the upregulation of TRPV1 expression caused by constipation. LP-CQPC02 exerted a stronger effect than LB, and LP-CQPC02 inhibited the upregulation of TRPV1 expression with an increasing dose. 
TABLE 2: Activated carbon propulsion rate of mice with activated carbon-induced constipation.

\begin{tabular}{lccc}
\hline Group & Length of small intestine $(\mathrm{cm})$ & Activated carbon propulsion distance $(\mathrm{cm})$ & Activated carbon propulsion rate $(\%)$ \\
\hline Normal & $48.8 \pm 2.4^{\mathrm{a}}$ & $48.8 \pm 2.4^{\mathrm{a}}$ & $100.0 \pm 0.0^{\mathrm{a}}$ \\
Control & $46.0 \pm 3.5^{\mathrm{a}}$ & $12.8 \pm 2.5^{\mathrm{d}}$ & $27.8 \pm 2.6^{\mathrm{e}}$ \\
LB & $43.4 \pm 1.7^{\mathrm{ab}}$ & $15.6 \pm 1.5^{\mathrm{cd}}$ & $35.9 \pm 1.6^{\mathrm{d}}$ \\
LP-CQPC02-L & $41.4 \pm 1.3^{\mathrm{b}}$ & $20.7 \pm 1.7^{\mathrm{c}}$ & $50.0 \pm 2.4^{\mathrm{c}}$ \\
LP-CQPC02-H & $45.2 \pm 3.9^{\mathrm{a}}$ & $27.0 \pm 1.6^{\mathrm{b}}$ & $59.7 \pm 3.2^{\mathrm{b}}$ \\
\hline
\end{tabular}

The values presented are the mean \pm standard deviation. ${ }^{\mathrm{a}-\mathrm{e}}$ The mean values with different letters in the same row are significantly different $(p<0.05)$ according to Duncan's multiple-range test. LB:Lactobacillus delbrueckii subsp. bulgaricus $\left(1.0 \times 10^{9} \mathrm{CFU} / \mathrm{kg}\right.$ b.w. gavage); LP-CQPC02-L: Lactobacillus plantarum CQPC02 $\left(1.0 \times 10^{8} \mathrm{CFU} / \mathrm{kg}\right.$ b.w. gavage); and LP-CQPC02-H: Lactobacillus plantarum CQPC02 $\left(1.0 \times 10^{9} \mathrm{CFU} / \mathrm{kg}\right.$ b.w. gavage).

TABle 3: MTL, Gas, ET, SS, and AChE serum levels in mice with activated carbon-induced constipation.

\begin{tabular}{lccccc}
\hline Levels (ng/L) & Normal & Control & LB & LP-CQPC02-L & LP-CQPC02-H \\
\hline MTL & $11.67 \pm 1.62^{\mathrm{a}}$ & $6.94 \pm 2.30^{\mathrm{c}}$ & $8.26 \pm 1.50^{\mathrm{b}}$ & $9.05 \pm 0.96^{\mathrm{b}}$ & $10.04 \pm 1.34^{\mathrm{ab}}$ \\
Gas & $10.38 \pm 0.39^{\mathrm{a}}$ & $6.13 \pm 1.62^{\mathrm{b}}$ & $6.38 \pm 2.30^{\mathrm{b}}$ & $7.05 \pm 1.64^{\mathrm{b}}$ & $9.97 \pm 0.68^{\mathrm{a}}$ \\
ET & $10.13 \pm 0.59^{\mathrm{a}}$ & $7.11 \pm 1.65^{\mathrm{c}}$ & $7.48 \pm 1.26^{\mathrm{c}}$ & $9.52 \pm 0.49^{\mathrm{b}}$ & $9.85 \pm 0.49^{\mathrm{ab}}$ \\
SS & $5.20 \pm 1.05^{\mathrm{c}}$ & $8.76 \pm 0.98^{\mathrm{a}}$ & $8.72 \pm 2.31^{\mathrm{a}}$ & $7.51 \pm 2.34^{\mathrm{ab}}$ & $7.00 \pm 1.34^{\mathrm{ab}}$ \\
AChE & $11.45 \pm 0.56^{\mathrm{a}}$ & $7.49 \pm 0.68^{\mathrm{b}}$ & $7.91 \pm 0.78^{\mathrm{b}}$ & $8.37 \pm 0.83^{\mathrm{ab}}$ & $10.73 \pm 2.69^{\mathrm{a}}$ \\
\hline
\end{tabular}

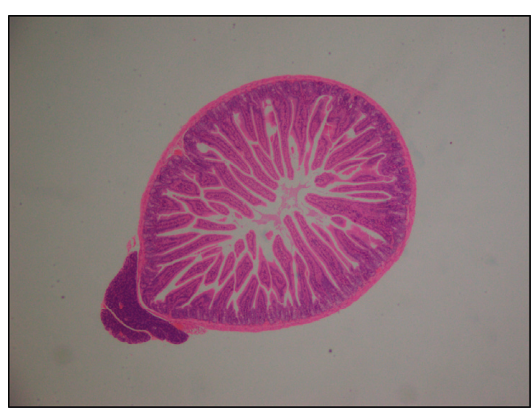

(a)

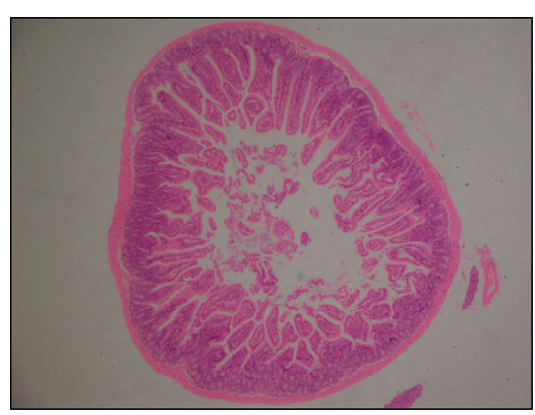

(c)

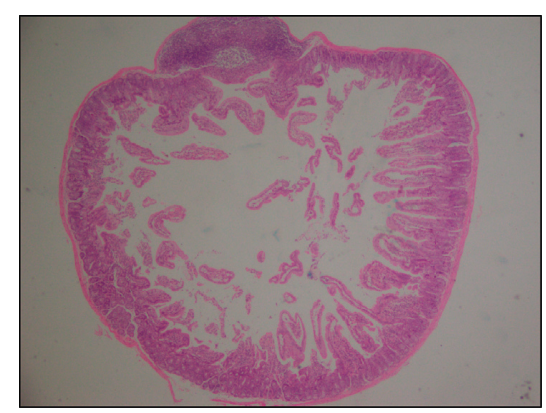

(b)

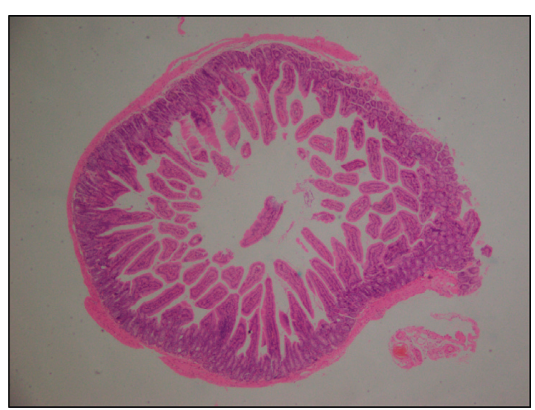

(d)

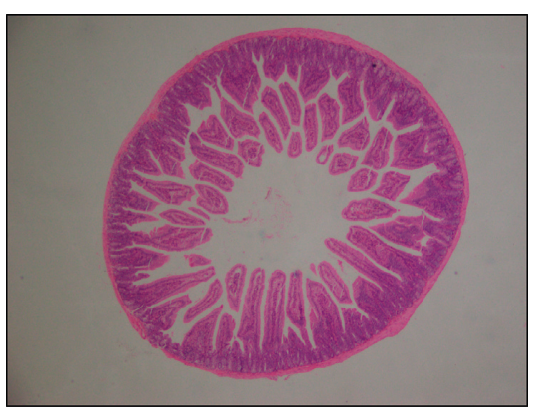

(e)

FIgURE 3: Morphological observation of small intestine tissue in mice with activated carbon-induced constipation. LB:Lactobacillus delbrueckii subsp. bulgaricus $\left(1.0 \times 10^{9} \mathrm{CFU} / \mathrm{kg}\right.$ b.w. gavage); LP-CQPC02-L: Lactobacillus plantarum CQPC02 $\left(1.0 \times 10^{8} \mathrm{CFU} / \mathrm{kg}\right.$ b.w. gavage); and LP-CQPC02-H : Lactobacillus plantarum CQPC02 $\left(1.0 \times 10^{9} \mathrm{CFU} / \mathrm{kg}\right.$ b.w. gavage). (a) Normal. (b) Control. (c) LB. (d) LPCQPC02-L. (e) LP-CQPC02-H. 


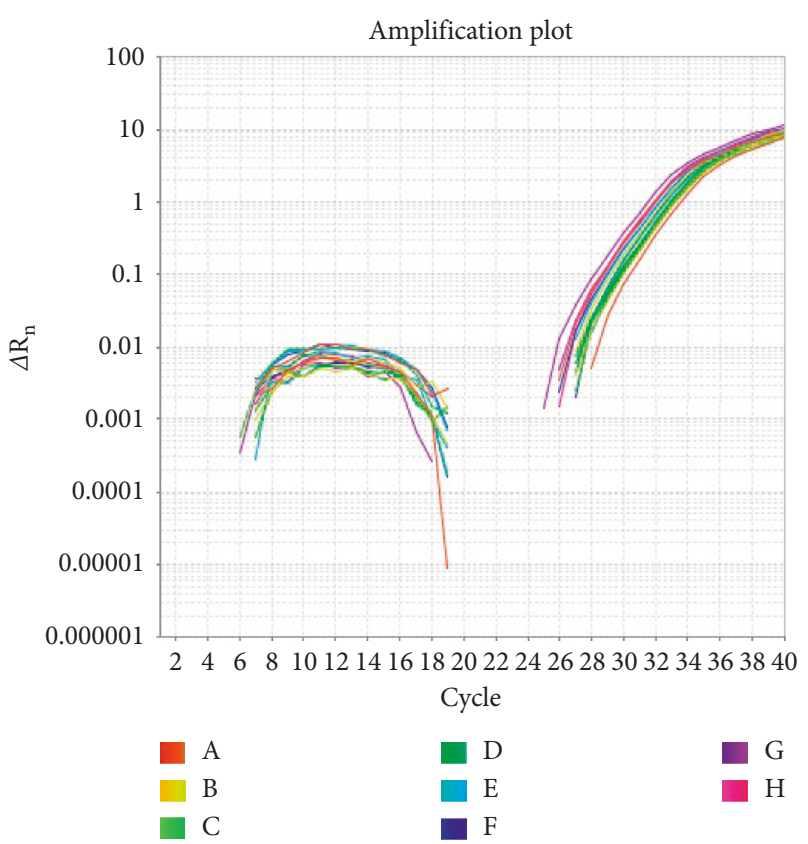

(a)

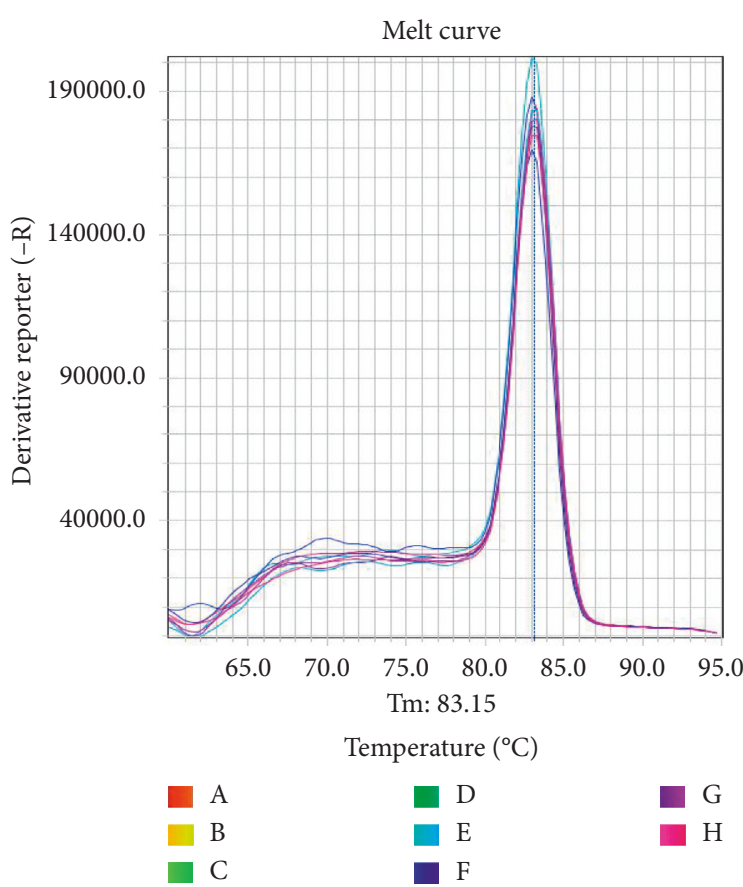

(b)

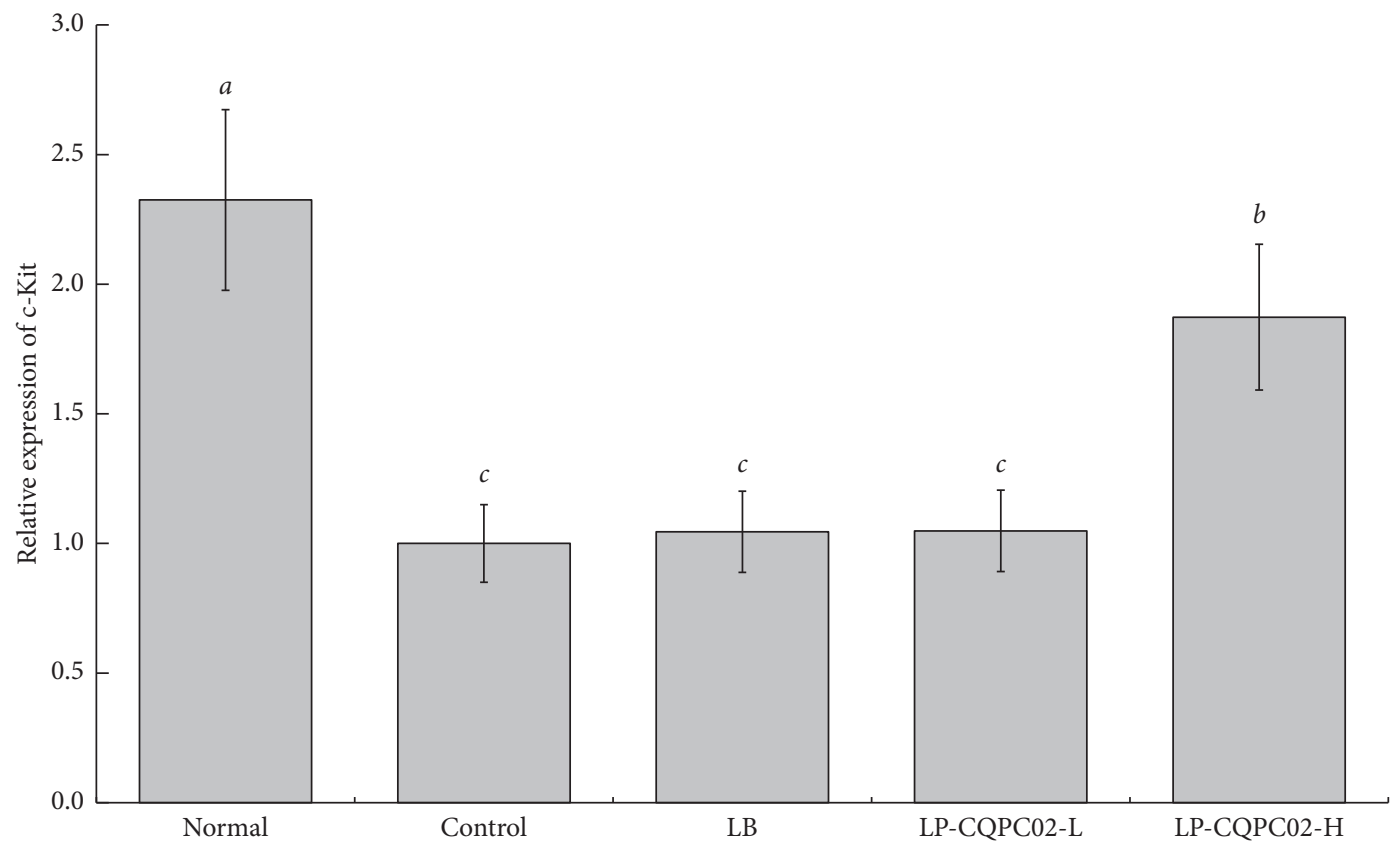

(c)

FIgURE 4: The mRNA expression level of c-Kit in the small intestine tissue of mice. (a) Amplification curve, (b) dissolution curve, and (c) relative expression. Values presented are the mean \pm standard deviation. ${ }^{\mathrm{a}-\mathrm{c}}$ The mean values with different letters in the same bars are significantly different $(p<0.05)$ according to Duncan's multiple-range test; there was no significant difference in the same letter representation between the two bars $(p>0.05)$, but there was significant difference in the different letter representation $(p<0.05)$. LB: Lactobacillus delbrueckii subsp. bulgaricus $\left(1.0 \times 10^{9} \mathrm{CFU} / \mathrm{kg}\right.$ b.w. gavage); LP-CQPC02-L:Lactobacillus plantarum CQPC02 $\left(1.0 \times 10^{8} \mathrm{CFU} / \mathrm{kg}\right.$ b.w. gavage $)$; and LP-CQPC02-H : Lactobacillus plantarum CQPC02 $\left(1.0 \times 10^{9} \mathrm{CFU} / \mathrm{kg}\right.$ b.w. gavage $)$.

3.10. iNOS mRNA Expression in the Small Intestine of Mice. The expression of iNOS in the small intestine of the control group mice was significantly $(p<0.05)(p<0.05)$ higher than that of the other groups, while the expression of iNOS in the small intestine of the normal group mice was significantly $(p<0.05)$ lower than that of the other groups (Figure 8). The expression of iNOS in the small intestine of LP-CQPC02-H, LP-CQPC02-L, and LB mice increased in turn. The expression of iNOS in the small intestine of LPCQPC02-H mice was the closest to that of the normal mice. 


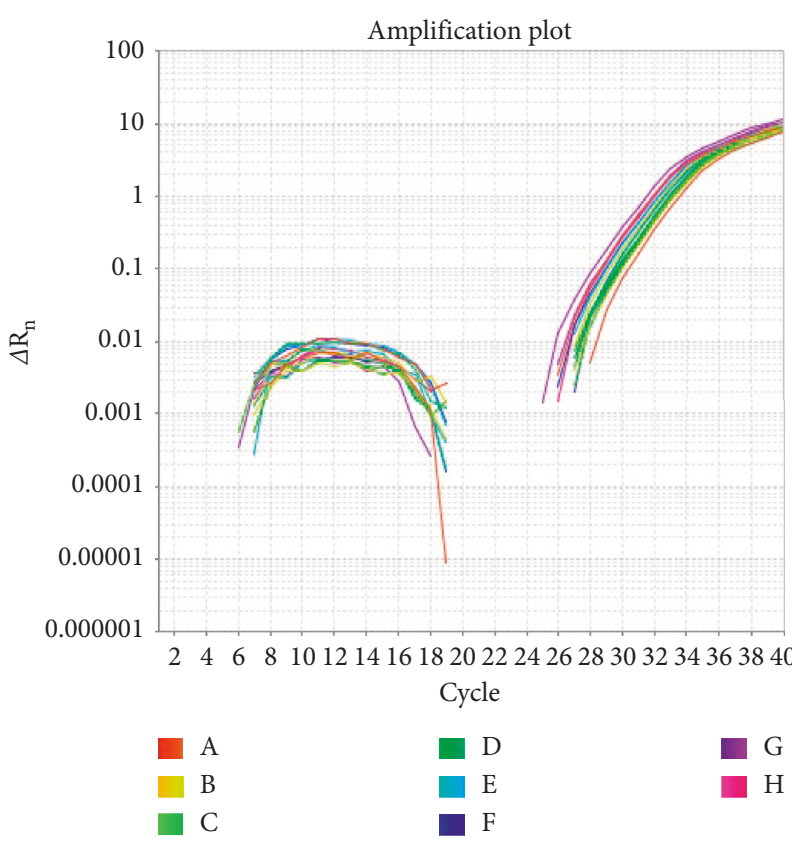

(a)

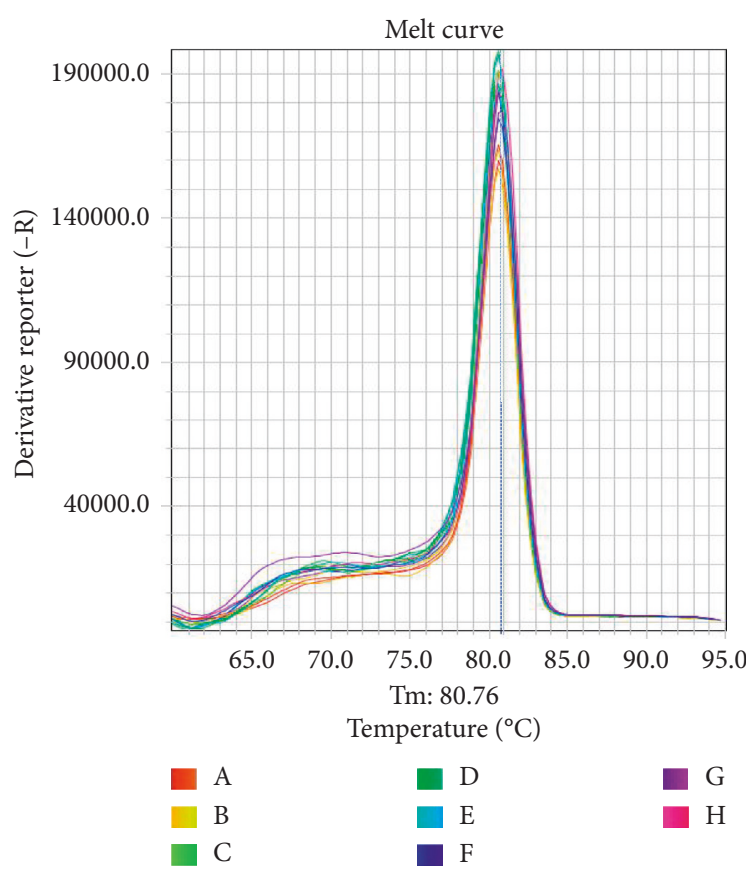

(b)

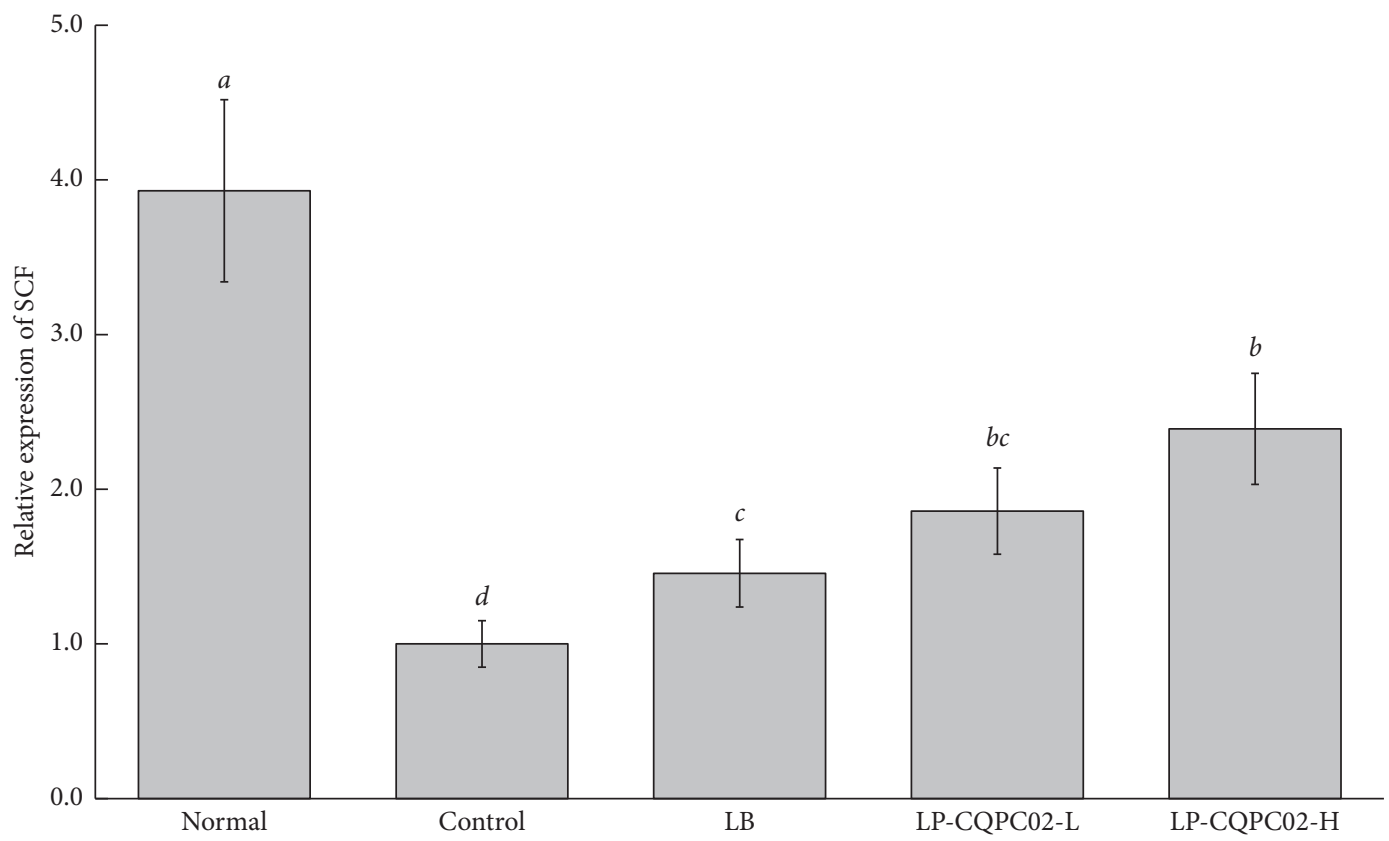

(c)

Figure 5: The mRNA expression level of SCF in the small intestine tissue of mice. (a) Amplification curve, (b) dissolution curve, and (c) relative expression. Values presented are the mean \pm standard deviation. ${ }^{\mathrm{a}-\mathrm{d}}$ The mean values with different letters in the same bars are significantly different $(p<0.05)$ according to Duncan's multiple-range test; there was no significant difference in the same letter representation between the two bars $(p>0.05)$, but there was significant difference in the different letter representation $(p<0.05)$. LB: Lactobacillus delbrueckii subsp. bulgaricus $\left(1.0 \times 10^{9} \mathrm{CFU} / \mathrm{kg}\right.$ b.w. gavage); LP-CQPC02-L:Lactobacillus plantarum CQPC02 $\left(1.0 \times 10^{8} \mathrm{CFU} / \mathrm{kg}\right.$ b.w. gavage $)$; and LP-CQPC02-H: Lactobacillus plantarum CQPC02 $\left(1.0 \times 10^{9} \mathrm{CFU} / \mathrm{kg}\right.$ b.w. gavage $)$.

\section{Discussion}

Constipation is a common intestinal disorder in the population that mainly manifests as difficult defecation, irregular defecation, and dry excreta. Clinical observation shows that constipation can cause body weight loss [19], and a previous study showed that mice with induced constipation can also lose weight and that constipation in animals can cause slow weight gain or weight loss [20]. Our experimental 


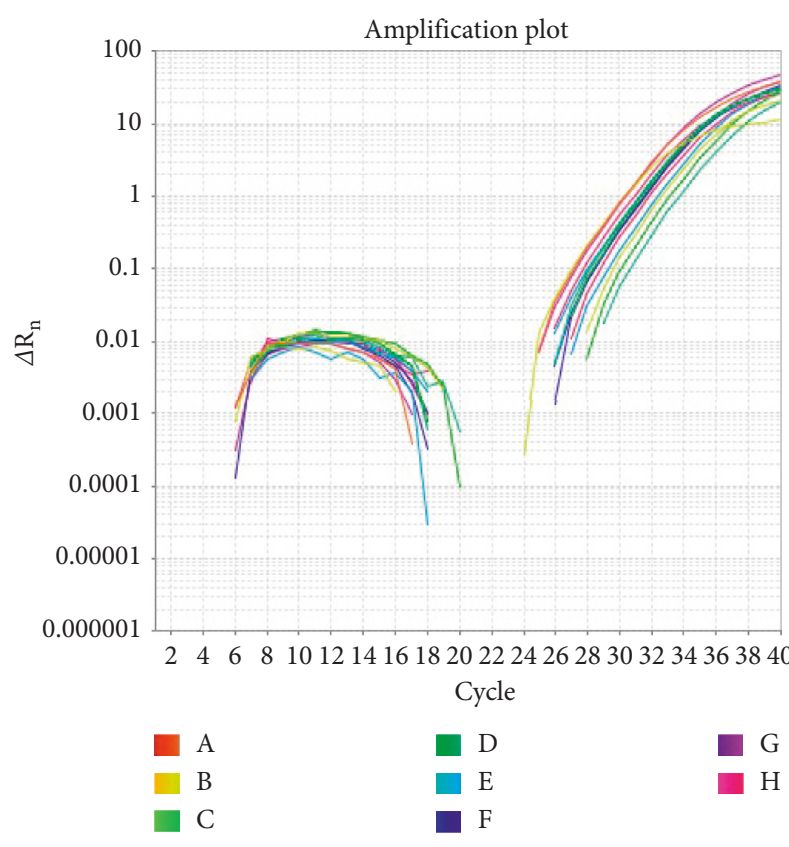

(a)

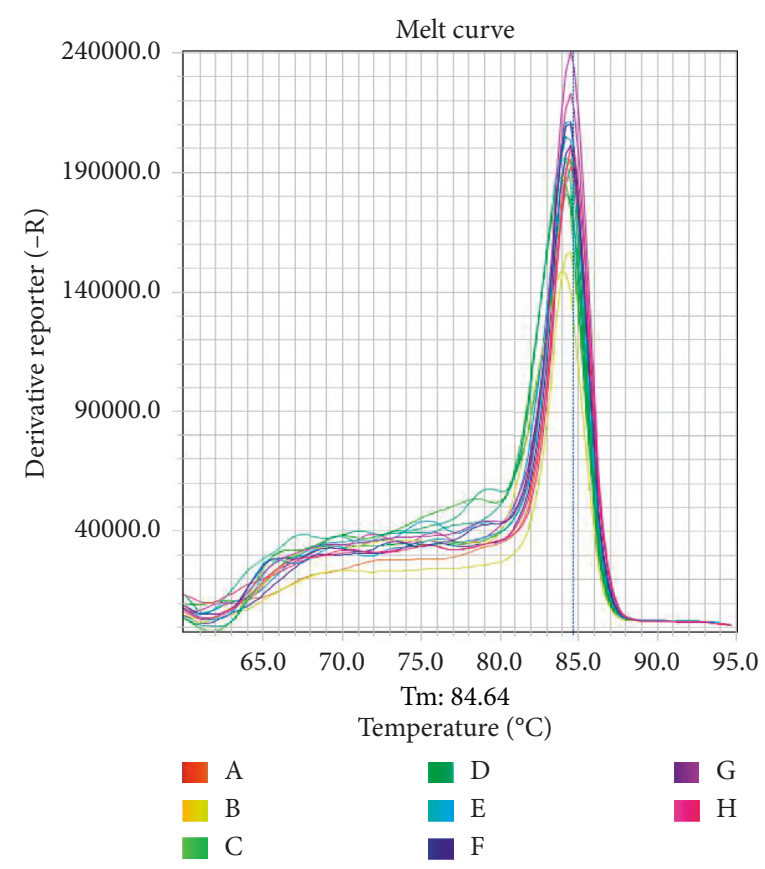

(b)

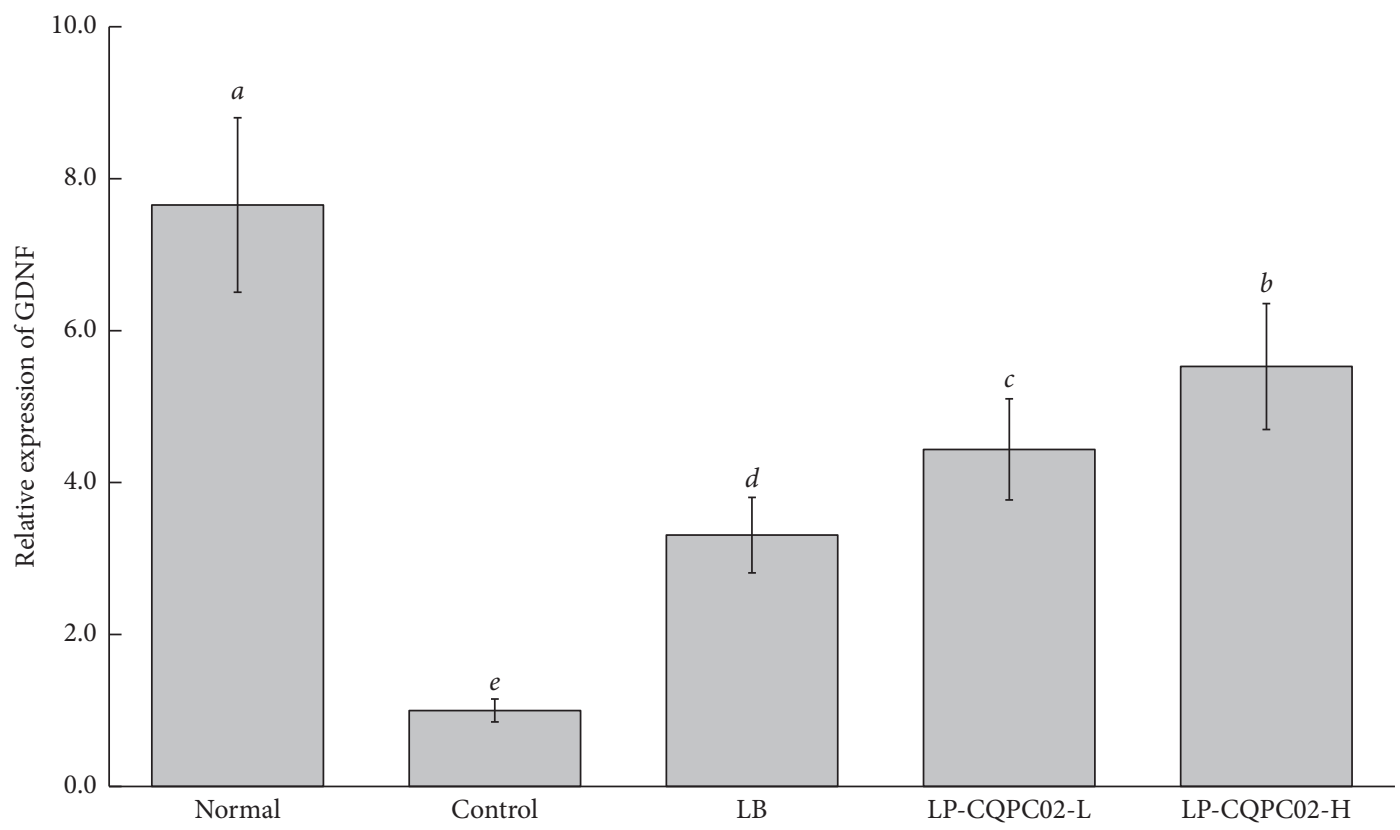

(c)

Figure 6: The mRNA expression level of GDNF in the small intestine tissue of mice. (a) Amplification curve, (b) dissolution curve, and (c) relative expression. Values presented are the mean \pm standard deviation. ${ }^{\mathrm{a}-\mathrm{d}}$ The mean values with different letters in the same bars are significantly different $(p<0.05)$ according to Duncan's multiple-range test; there was no significant difference in the same letter representation between the two bars $(p>0.05)$, but there was significant difference in the different letter representation $(p<0.05)$. LB: Lactobacillus delbrueckii subsp. bulgaricus $\left(1.0 \times 10^{9} \mathrm{CFU} / \mathrm{kg}\right.$ b.w. gavage); LP-CQPC02-L:Lactobacillus plantarum CQPC02 $\left(1.0 \times 10^{8} \mathrm{CFU} / \mathrm{kg}\right.$ b.w. gavage $)$; and LP-CQPC02-H : Lactobacillus plantarum CQPC02 $\left(1.0 \times 10^{9} \mathrm{CFU} / \mathrm{kg}\right.$ b.w. gavage $)$.

results show that LP-CQPC02 has a good inhibitory effect on the weight loss of mice caused by constipation.

In the constipation state, the peristalsis rate of the small intestine will decrease, and the feces in the small intestine cannot flow through the small intestine normally and remain inside, thus breeding bacteria to further increase the degree of constipation, forming a vicious circle. As a result of constipation, intestinal motility slows down, resulting in feces remaining in the intestinal tract for a longer time, so that the first black stool discharge time increases. Animal experimentation has proven that for the intestinal tract in the normal state, the first black stool discharge time is 


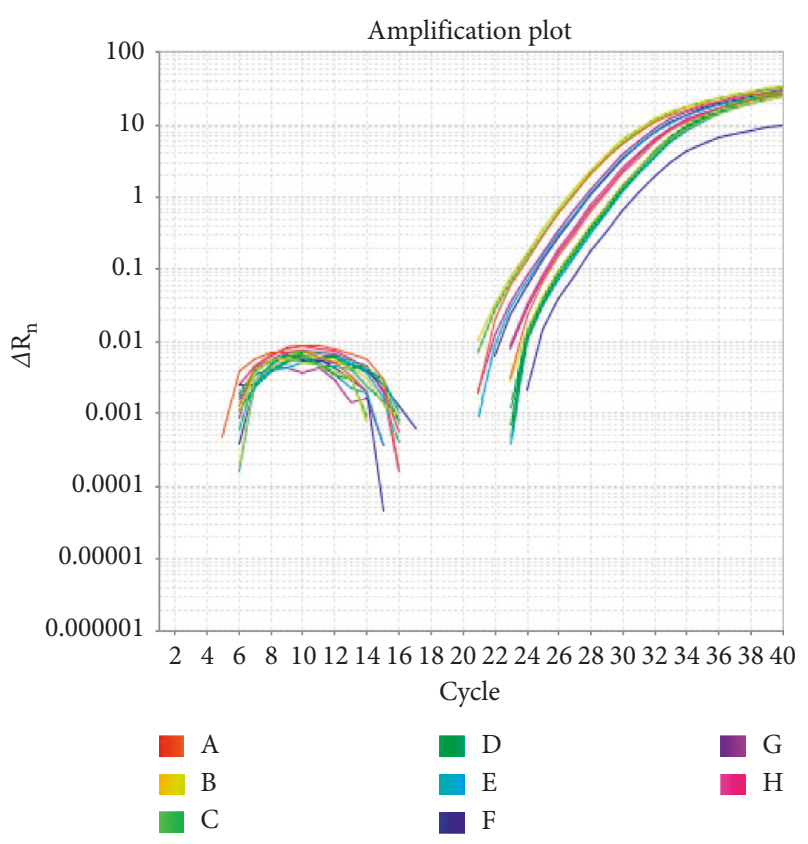

(a)

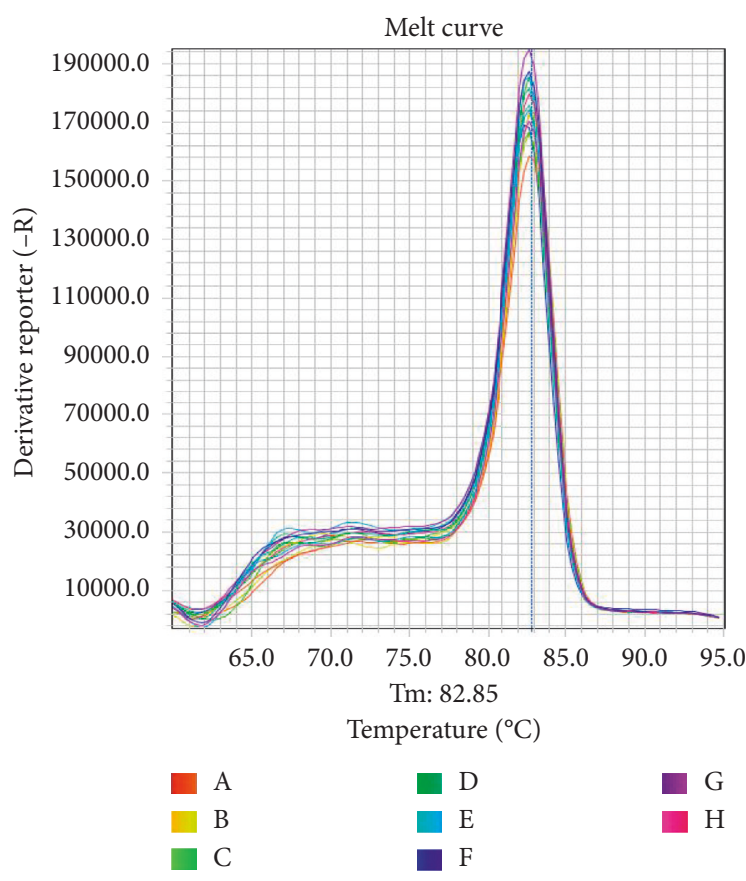

(b)

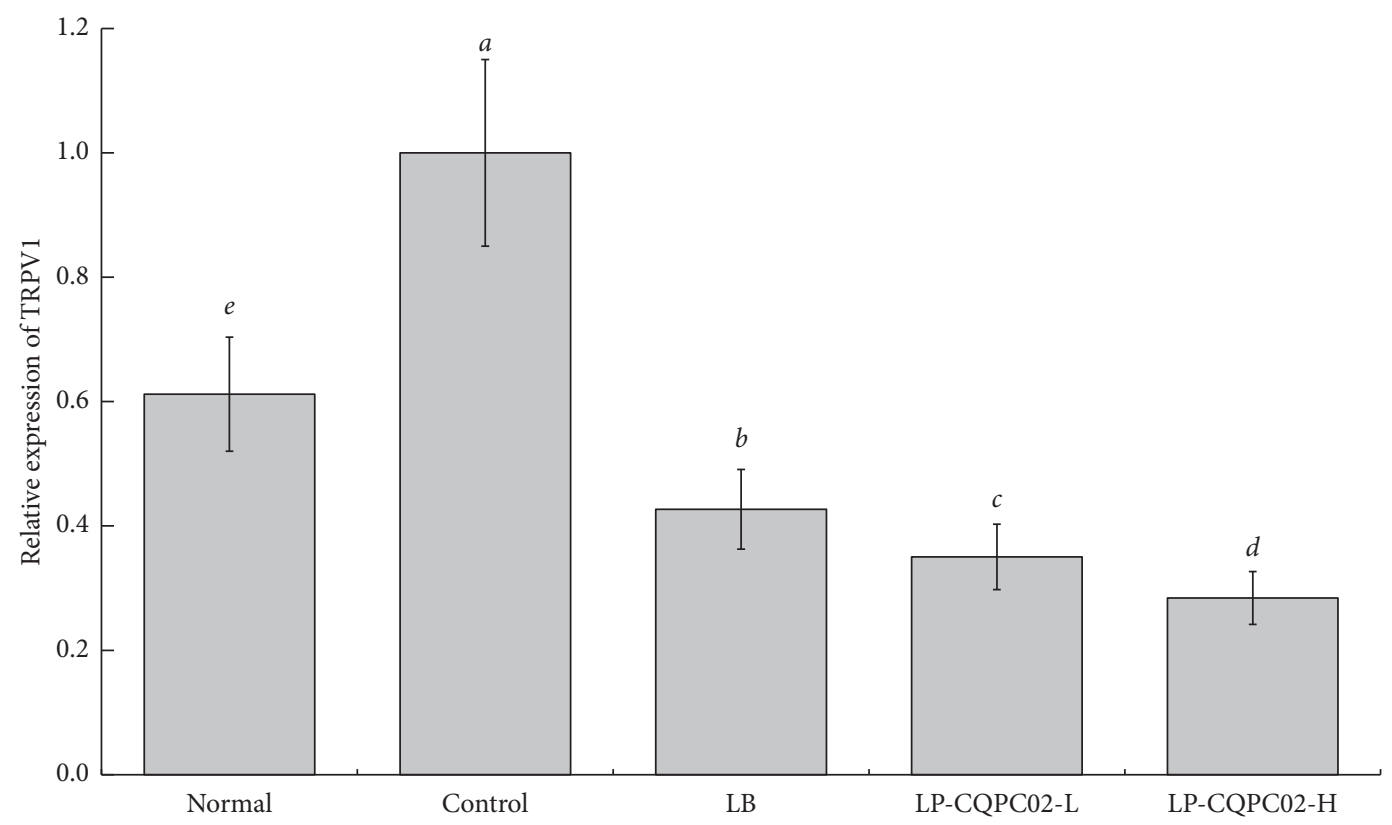

(c)

FIGURE 7: mRNA expression level of TRPV1 in the small intestine tissue of mice. (a) Amplification curve, (b) dissolution curve, and (c) relative expression. Values presented are the mean \pm standard deviation. ${ }^{\text {a-d }}$ The mean values with different letters in the same bars are significantly different $(p<0.05)$ according to Duncan's multiple-range test; there was no significant difference in the same letter representation between the two bars $(p>0.05)$, but there was significant difference in the different letter representation $(p<0.05)$. LB: Lactobacillus delbrueckii subsp. bulgaricus $\left(1.0 \times 10^{9} \mathrm{CFU} / \mathrm{kg}\right.$ b.w. gavage); LP-CQPC02-L:Lactobacillus plantarum CQPC02 $\left(1.0 \times 10^{8} \mathrm{CFU} / \mathrm{kg}\right.$ b.w. gavage); and LP-CQPC02-H : Lactobacillus plantarum CQPC02 $\left(1.0 \times 10^{9} \mathrm{CFU} / \mathrm{kg}\right.$ b.w. gavage).

shorter, and in the constipation state, the first black stool discharge time is longer [16]. Another experiment proved that proper supplementation of probiotics can reduce the symptoms of constipation [18]. The current study also proved that LP-CQPC02 can inhibit constipation in mice through the first defecation time.
Pathological observation shows that constipation can lead to small intestinal injury and affect the shape of the small intestinal wall and villi. The degree of constipation can be judged by observing the pathological morphology of the small intestine [18]. In the current study, H\&E staining showed that LP-CQPC02 can effectively alleviate the tissue 


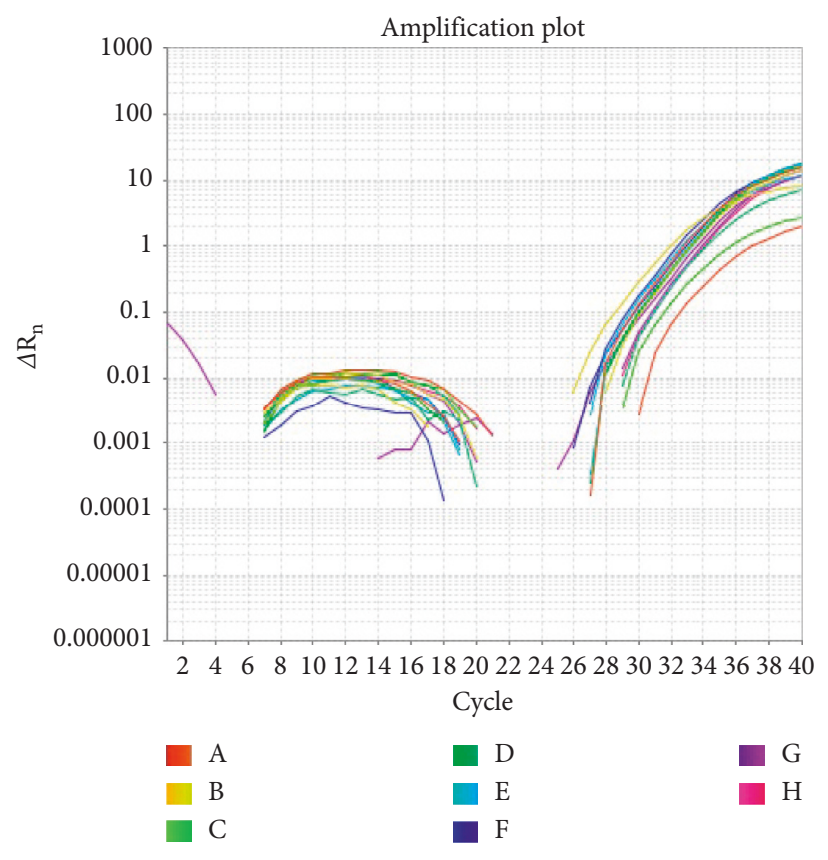

(a)

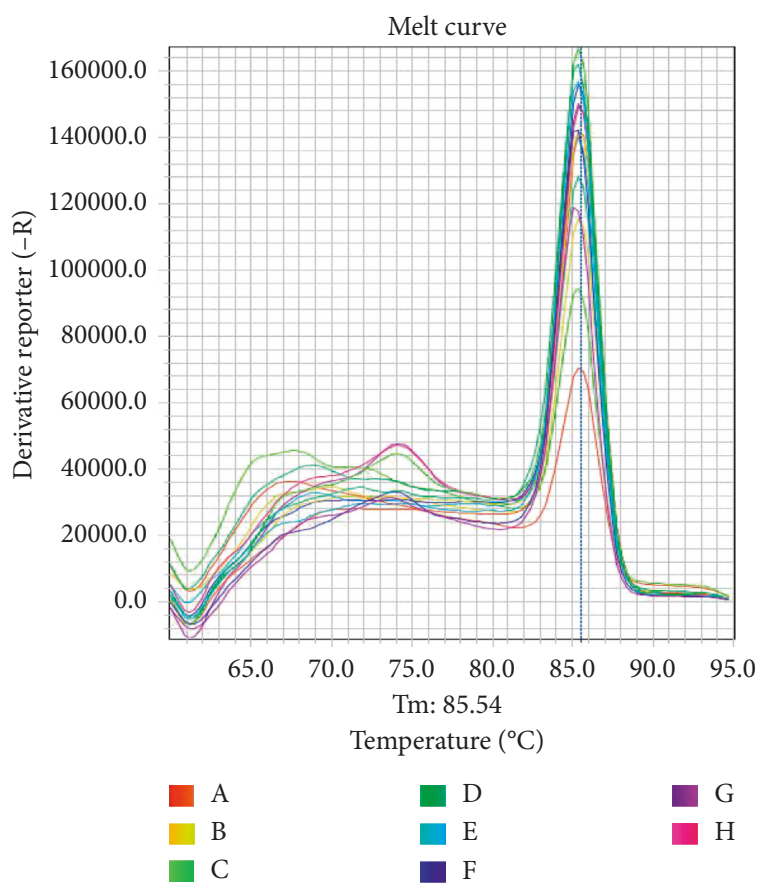

(b)

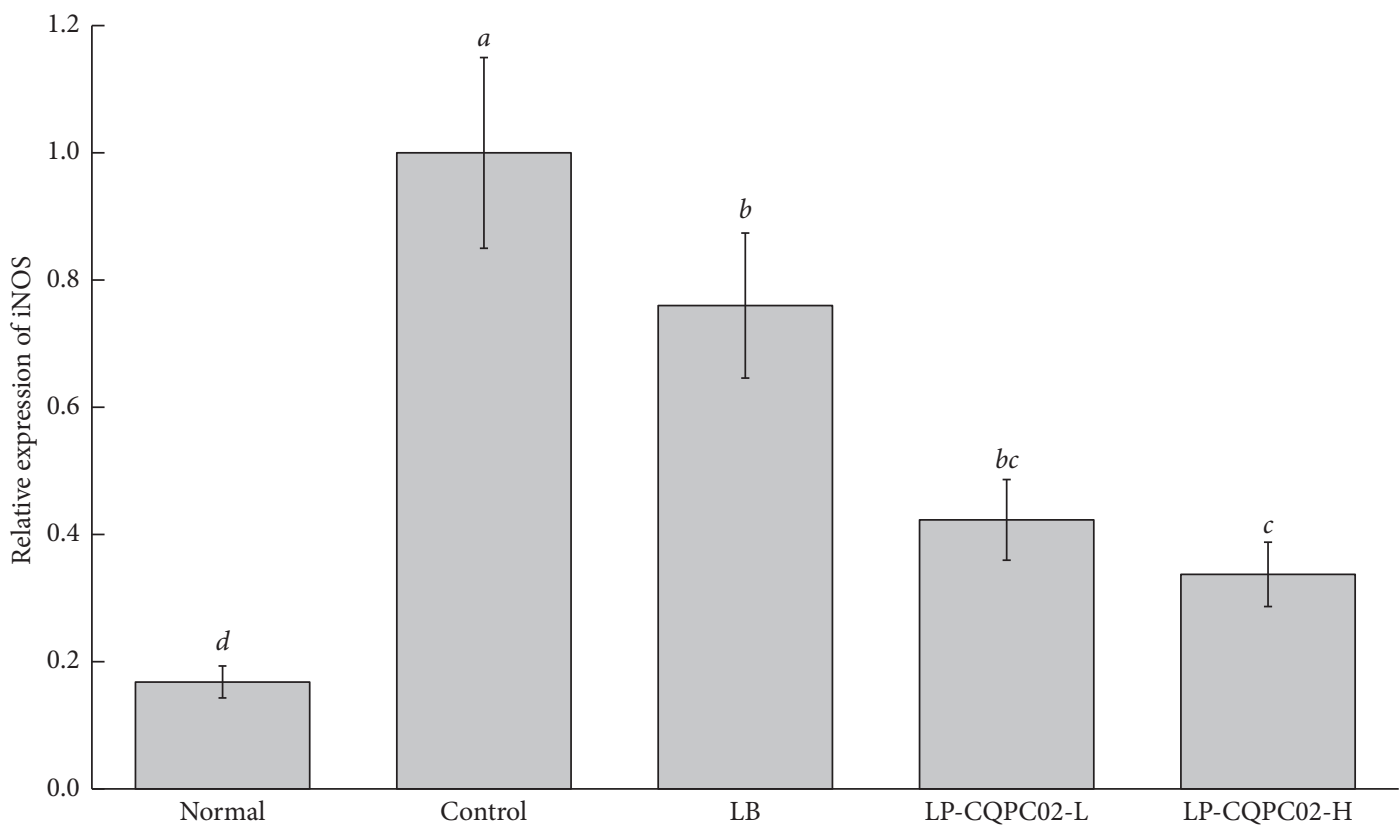

(c)

Figure 8: The mRNA expression level of iNOS in the small intestine tissue of mice. (a) Amplification curve, (b) dissolution curve, and (c) relative expression. The values presented are the mean \pm standard deviation. ${ }^{\mathrm{a}-\mathrm{d}}$ The mean values with different letters in the same bars are significantly different $(p<0.05)$ according to Duncan's multiple-range test; there was no significant difference in the same letter representation between the two bars $(p>0.05)$, but there was significant difference in the different letter representation $(p<0.05)$. LB: Lactobacillus delbrueckii subsp. bulgaricus $\left(1.0 \times 10^{9} \mathrm{CFU} / \mathrm{kg}\right.$ b.w. gavage); LP-CQPC02-L:Lactobacillus plantarum CQPC02 $\left(1.0 \times 10^{8} \mathrm{CFU} / \mathrm{kg}\right.$ b.w. gavage); and LP-CQPC02-H: Lactobacillus plantarum CQPC02 $\left(1.0 \times 10^{9} \mathrm{CFU} / \mathrm{kg}\right.$ b.w. gavage $)$.

damage in the small intestine caused by constipation and thus alleviate constipation.

Clinical studies have shown that changes occur in ET, SS, MTL, Gas, and AChE levels in patients with constipation $[21,22]$. ET plays an important role in the stability of vascular tension and maintenance of the basic cardiovascular system and can improve intestinal vitality [18]. SS can stimulate intestinal motility, prevent decreases in the gastric emptying rate, strengthen smooth muscle contraction, and relieve constipation [23]. MTL can stimulate pepsin 
production and promote intestinal motility, and a reduction in MTL release will reduce gastrointestinal peristalsis [24]. Gas has a significant role in alleviating constipation because it can promote gastrointestinal secretion and gastrointestinal motility, as well as promoting pyloric relaxation [25]. AChE is an important neurotransmitter in intestinal motility, and it can regulate muscle contraction and mucus secretion, relax muscles, and promote the excretion of feces [26]. Our study also confirmed that LP-CQPC02 alleviated the effects of constipation on mice, and the ET, SS, MTL, Gas, and AChE levels were similar to those of the normal mice.

ICCs (interstitial Cajal cells) are the pacemaker cells that cause an intestinal slow wave, and ICCs also play a role in intestinal nerve signal transmission; therefore, gastrointestinal function is affected by ICCs [27]. A study has shown that the density of ICCs in the intestinal tract of constipation patients is lower than normal, which leads to a decrease in the postsynaptic reaction of ICCs and neurotransmitters. This results in the loss of the role of ICCs in spontaneous slow wave rhythm, resulting in irregular colonic motility and affecting intestinal function [28]. c-Kit can be used as a marker for ICCs to indicate ICC proliferation [29]. However, the concentration of SCF plays a decisive role in the reproduction of ICCs, as ICCs cannot grow in the absence of SCF. A previous study also showed that the expression of c-Kit in the colonic tissue of the control mice decreased if the ICC content in colonic tissue decreased [16]. Lactobacillus can effectively increase the content of c-Kit in the intestinal tract of constipated mice, increase the content of ICCs, promote intestinal peristalsis, and relieve constipation [18]. In our experiments, the expression of SCF and c-Kit also decreased in the small intestine of mice with constipation induced by activated carbon. LP-CQPC02 effectively increased the expression of SCF and c-Kit in the small intestine of constipated mice. The increase in the expression of SCF and c-Kit increased the expression of ICCs in the intestine of constipated mice, thus inhibiting constipation.

TRPV1 can affect constipation. After TRPV1 is stimulated, it releases neurotransmitters through protruding corpuscles and affects the normal peristalsis of the small intestine. The expression of TRPV1 in the small intestine will increase after the injury caused by constipation. Therefore, the expression of TRPV1 can indicate whether the small intestine is damaged or not. The intestinal damage caused by gastrointestinal diseases can also increase the expression of TRPV1 in patients with constipation [30]. The weakened gastrointestinal motility of constipation is intertwined with the intestinal nervous system, and GDNF can restore injured ganglion function to a certain extent, repair the injured intestine, and effectively inhibit constipation [31]. LPCQPC02 can reduce the expression of TRPV1, and also increase the expression of GDNF in the small intestine of constipated mice and thus alleviate constipation.

Nitric oxide synthase (NOS) participates in the regulation of gastrointestinal motility. An increase in NOS will lead to an increase in the nitric oxide (NO) content, affect intestinal function, and cause constipation [32]. A continuous increase in NO can cause colon dyskinesia with increased severity [33]. Endothelial dysfunction may cause constipation, and decreasing NO bioavailability is an important factor in endothelial dysfunction [34]. NO is synthesized by NOS. There are three different subtypes of NOS, including NOS1 (nNOS), NOS2 (iNOS), and NOS3 (eNOS). One of the main inhibitory neurotransmitters in the intestinal nervous system is iNOS, which causes smooth muscle relaxation and weakens gastrointestinal peristalsis. The iNOS content has been positively correlated with the amount of iNOS-positive fibers, and an increase in iNOS will affect intestinal function, leading to constipation. Therefore, controlling the amount of iNOS can prevent the occurrence of constipation [35]. iNOS is not expressed in the resting state, but increased amounts of iNOS and NO are produced [36] when the body is injured or under other pathological conditions. Reducing the levels of NOS and NO can alleviate constipation [37]. In our study, we found that LP-CQPC02 significantly downregulated the expression of iNOS, thus alleviating constipation.

In the artificial bile salt tolerance experiment in vitro, the survival rate of LP-CQPC02 in $0.3 \%$ bile salt was nearly $20 \%$ (unpublished data) after 24 hours, and the survival rate of LP-CQPC02 in artificial gastric juice at pH 3.0 was over 90\% after 3 hours, which showed that LP-CQPC02 could effectively enter the intestinal tract through the stomach and play its role for a long time.

In this study, the inhibitory effect of LP-CQPC02 on experimental constipation was examined. This bacterium is a newly isolated strain obtained from traditional natural fermentation of Paocai from Sichuan Province, China. Animal experiments showed that LP-CQPC02 alleviated constipation in mice, and biochemical tests on serum more fully prove that LP-CQPC02 inhibits constipation. Deep qPCR provided gene expression results that clarified the mechanism used by LP-CQPC02 to relieve constipation. LPCQPC02 can increase the normal physiological activity of the small intestine and alleviate constipation by enhancing intestinal motility, maintaining intestinal health, and inhibiting the effect of constipation. The effect of LPCQPC10 is positively correlated with the dosage of bacteria used, and because it possesses a significantly stronger effect than that of commercial LB at the same concentration, it has good development and application value. Sexual maturity of mice was at the age of 6-7 weeks; this study focused on the role of CQPC02 in adult animals. Further studies on the effects of LP-CQPC02 on mice at different ages are needed in future experiments.

\section{Data Availability}

No data were used to support this study.

\section{Conflicts of Interest}

There are no conflicts of interest in this paper.

\section{Authors' Contributions}

Bihui Liu and Xin Yang contributed equally to this work. Bihui Liu and Xin Yang performed the majority of the 
experiments and wrote the manuscript; Liujin Guo, Jing Zhang, Xianrong Zhou, and Ruokun Yi contributed to the data analysis; Xin Zhao designed and supervised the study and read the final manuscript.

\section{Acknowledgments}

This research was funded by the Program for Innovation Team Building at Institutions of Higher Education in Chongqing (CXTDX201601040) and the Research Project of Chongqing University of Education (KY2015TBZC), China.

\section{References}

[1] G. Chen, W. H. Yu, Q. S. Zhang et al., "Research of sichuan paocai and lactic acid bacteria," Advance Journal of Food Science and Technology, vol. 6, no. 1, pp. 1-5, 2014.

[2] J. X. Yang, L. L. Zhang, H. Y. Jiang, and Z. F. He, "Isolation and identification of lactic bacteria in pickled vegetavles from Meishan city," Food Science, vol. 36, no. 7, pp. 158-163, 2015.

[3] H. Liang, L. Yin, Y. Zhang, C. Chang, and W. Zhang, "Dynamics and diversity of a microbial community during the fermentation of industrialized Qingcai paocai, a traditional Chinese fermented vegetable food, as assessed by Illumina MiSeq sequencing, DGGE and qPCR assay," Annals of Microbiology, vol. 68, no. 2, pp. 111-122, 2018.

[4] Y. Qian, J.-L. Song, R. Yi et al., "Preventive effects of Lactobacillus plantarum YS4 on constipation induced by activated carbon in mice," Applied Science, vol. 8, no. 3, p. 363, 2018.

[5] X. Chen, X. Zhao, H. Wang, Z. Yang, J. Li, and H. Suo, "Prevent effects of Lactobacillus fermentum HY01 on dextran sulfate sodium-induced colitis in mice," Nutrients, vol. 9, no. 6 , p. 545, 2017.

[6] X. Chen, J. Zhang, R. Yi, J. Mu, X. Zhao, and Z. Yang, "Hepatoprotective effects of Lactobacillus on carbon tetrachloride-induced acute liver injury in mice," International Journal of Molecular Sciences, vol. 19, no. 8, p. 2212, 2018.

[7] X. Chen, F. Tan, R. Yi, J. Mu, X. Zhao, and Z. Yang, "Effects of Lactobacillus on mice with diabetes induced by high-fat diet with streptozotocin (STZ)," Applied Sciences, vol. 8, no. 8, p. 1249, 2018.

[8] E. Persichetti, A. De Michele, M. Codini, and G. Traina, "Antioxidative capacity of Lactobacillus fermentum LF31 evaluated in vitro by oxygen radical absorbance capacity assay," Nutrition, vol. 30, no. 7-8, pp. 936-938, 2014.

[9] J. Zhang, X. Zhou, B. Chen et al., "Preventive effect of Lactobacillus plantarum CQPC10 on activated carbon induced constipation in institute of cancer research (ICR) mice," Applied Sciences, vol. 8, no. 9, p. 1498, 2018.

[10] N. G. Marengoni and D. M. Albuquerque, "Quantification of intestinal bacteria, operating cost and performance of fingerlings Nile tilapia subjected to probiotics," Latin American Journal of Aquatic Research, vol. 43, no. S2, pp. 367-373, 2015.

[11] A. W. Nichols, "Probiotics and athletic performance: a systematic review," Current Sports Medicine Reports, vol. 6, no. 4, pp. 269-273, 2007.

[12] G. Ianiro, M. Pizzoferrato, F. Franceschi, A. Tarullo, T. Luisi, and G. Gasbarrini, "Effect of an extra-virgin olive oil enriched with probiotics or antioxidants on functional dyspepsia: a pilot study," European Review for Medical and Pharmacological Sciences, vol. 17, no. 15, pp. 2085-2090, 2013.
[13] J. L. Balcazar, I. D. Blas, I. Ruiz-Zarzuela et al., "Enhancement of the immune response and protection induced by probiotic lactic acid bacteria against furunculosis in rainbow trout (Oncorhynchus mykiss)," Pathogens and Disease, vol. 51, no. 1, pp. 185-193, 2013.

[14] S. Pavan, P. Desreumaux, and A. Mercenier, "Use of mouse models to evaluate the persistence, safety, and immune modulation capacities of lactic acid bacteria," Clinical and Diagnostic Laboratory Immunology, vol. 10, no. 4, pp. 696701, 2003.

[15] X. Chen, J.-L. Song, Q. Hu, H. Wang, X. Zhao, and H. Suo, "Positive enhancement of Lactobacillus fermentum HY01 on intestinal movements of mice having constipation," Applied Biological Chemistry, vol. 61, no. 1, pp. 39-48, 2018.

[16] X. Zhao, R. K. Yi, Y. Qian, and K. Y. Park, "Lactobacillus plantarum YS-3 prevents activated carbon-induced constipation in mice," Journal of Medicinal Food, vol. 21, no. 6, pp. 575-584, 2018.

[17] X. P. Zhao, X. Y. Xiao, R. Cai, Z. J. Tan, and D. D. Li, "The progress in research of constipation-related gut microbes," Chinese Journal of Microecology, vol. 10, no. 10, pp. 1236-1241, 2014.

[18] J. Zhang, B. Chen, B. Liu et al., "Preventive effect of Lactobacillus fermentum CQPC03 on activated carbon-induced constipation in ICR mice," Medicina, vol. 54, no. 5, p. 89, 2018.

[19] C. K. Huang, M. Y. Wang, M. C. Hsin, and P. C. Chang, "Conversion to modified duodenal switch for relieving intractable dumping syndrome and constipation after laparoscopic Roux-en-Y gastric bypass," Obesity Surgery, vol. 25, no. 5, p. 946, 2015.

[20] H. Inagawa, T. Saika, N. Nishiyama et al., "Improvement effect of dewaxed brown rice on constipation in antibiotictreated mice," In Vivo, vol. 31, no. 4, pp. 573-577, 2017.

[21] B. C. Wang and F. Kang, "Clinical study on Tongle particles treatment of chronic functional constipation with Yin deficiency and intestinal dryness syndrome," China Journal of Chinese Medicine, vol. 30, no. 9, pp. 1354-1356, 2015.

[22] S. Y. Liu, Y. Liu, J. Y. Yao, Q. Zheng, L. Huang, and X. X. Guo, "Effects of traditional Chinese medicine fomentation on patients of functional constipation," Progress in Modern Biomedicine, vol. 14, no. 4, pp. 779-782, 2014.

[23] G. R. Gibson and M. B. Roberfroid, "Dietary modulation of the human colonic microbiota: updating the concept of prebiotics," Nutrition Research Reviews, vol. 17, no. 2, pp. 1401-1412, 2004.

[24] K. D. Setchell, N. M. Brown, L. Zimmer-Nechemias et al., "Evidence for lack of absorption of soy isoflavone glycosides in humans, supporting the crucial role of intestinal metabolism for bioavailability," American Journal of Clinical Nutrition, vol. 76, no. 2, pp. 447-453, 2002.

[25] L. Wang, L. Hu, Q. Xu et al., "Bifidobacterium adolescentis exerts strain-specific effects on constipation induced by loperamide in BALB/c mice," International Journal of Molecular Sciences, vol. 18, no. 2, p. 318, 2017.

[26] R. F. Furchgott and J. V. Zawadzki, "The obligatory role of endothelial cells in the relaxation of arterial smooth muscle by acetylcholine," Nature, vol. 288, no. 5789, pp. 373-376, 1980.

[27] K. M. Sanders, S. D. Koh, and S. M. Ward, "Interstitial cells of cajal as pacemakers in the gastrointestinal tract," Annual Review of Physiology, vol. 68, no. 1, pp. 307-343, 2006.

[28] G. Farrugia, "Interstitial cells of Cajal in health and disease," Neurogastroenterology and Motility, vol. 20, no. S1, pp. 54-63, 2010. 
[29] G. L. Lyford, C. L. He, E. Soffer et al., "Pan-colonic decrease in interstitial cells of Cajal in patients with slow transit constipation," Gut, vol. 51, no. 4, pp. 496-501, 2002.

[30] P. Geppetti and M. Trevisani, "Activation and sensitisation of the vanilloid receptor: role in gastrointestinal inflammation and function," British Journal of Pharmacology, vol. 141, no. 8, pp. 1313-1320, 2004.

[31] V. Shah, G. Lyford, G. Gores, and G. Farrugia, "Nitric oxide in gastrointestinal health and disease," Gastroenterology, vol. 126, no. 3, pp. 903-913, 2004.

[32] R. Tomita, S. Igarashi, S. Fujisaki, and K. Tanjoh, "The effects of neurotensin in the colon of patients with slow transit constipation," Hepatogastroenterology, vol. 54, no. 78, pp. 1662-1666, 2007.

[33] H. Xiao and L. Tang, "Progress of research on relationship between neuronal nitric oxide synthase and gastrointestinal motility disorders," Chinese Journal of Gastroenterology, vol. 22, no. 11, pp. 700-702, 2017.

[34] A. Forrest, M. Parsons, and M. Parsons, "The enhanced spontaneous activity of the diabetic colon is not the consequence of impaired inhibitory control mechanisms," Autonomic and Autacoid Pharmacology, vol. 23, no. 3, pp. 149-158, 2003.

[35] F. Vannini, K. Kashfi, and N. Nath, "The dual role of iNOS in cancer," Redox Biology, vol. 6, pp. 334-343, 2015.

[36] H. Sugiura, S. Okita, T. Kato et al., "Protection by taurine against INOS-dependent DNA damage in heavily exercised skeletal muscle by inhibition of the NF- $\kappa$ B signaling pathway," Advances in Experimental Medicine and Biology, vol. 775, pp. 237-246, 2013.

[37] L. Tan, Z. R. Tan, X. Huang, and L. R. Qin, "The expression of different kinds of NOS in the colon of slow transit constipation rats," Chinese Journal of Gastroenterology and Hepatology, vol. 20, no. 1, pp. 64-66, 2011. 


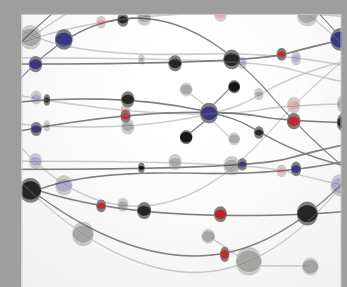

The Scientific World Journal
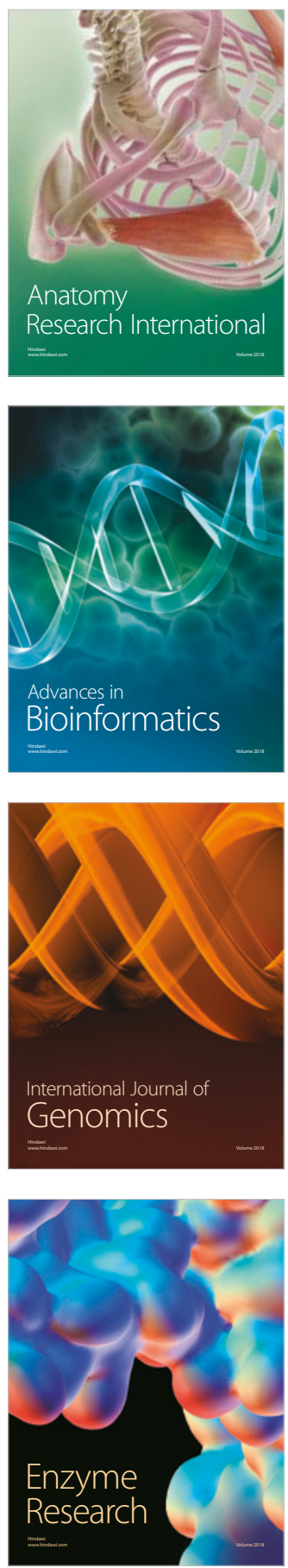
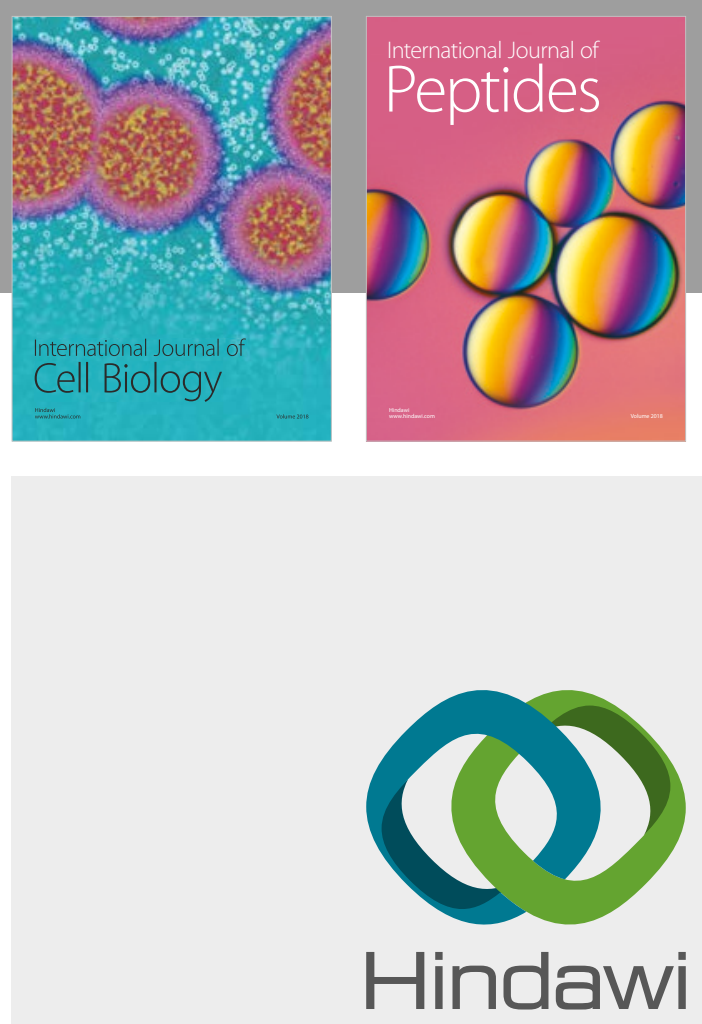

Submit your manuscripts at

www.hindawi.com
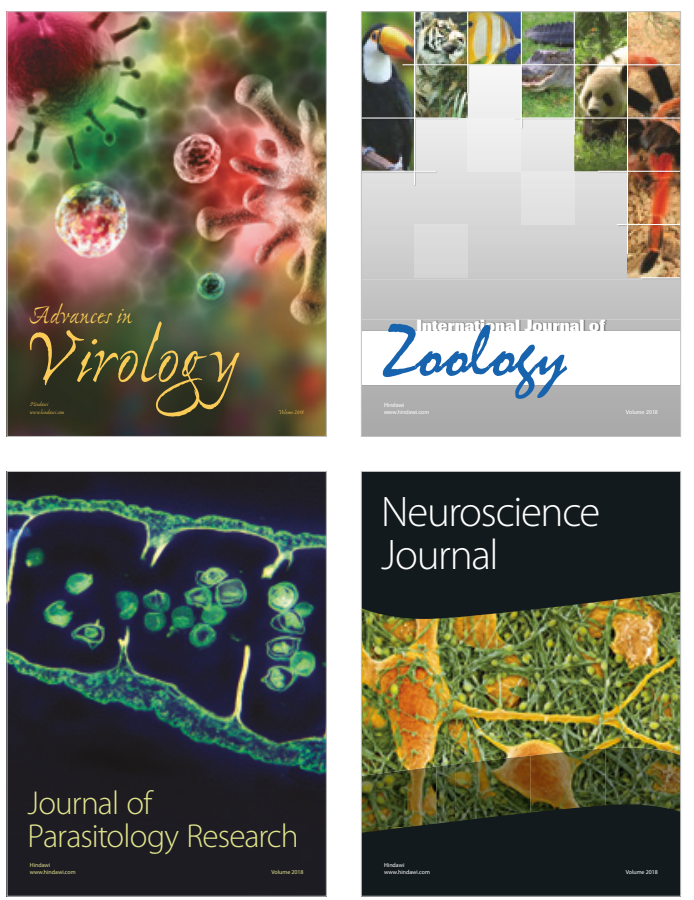
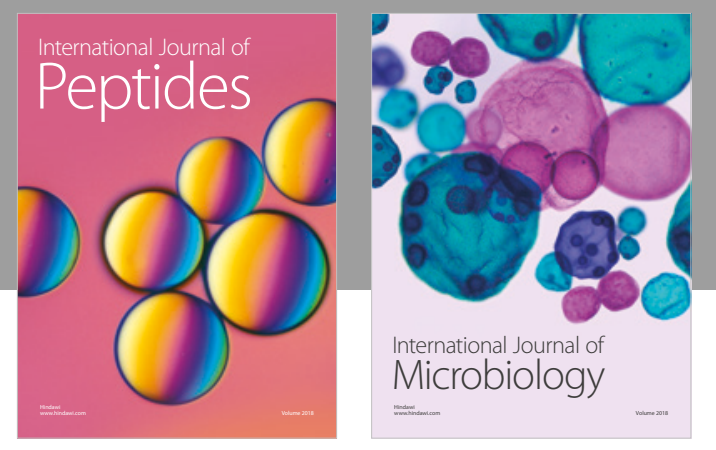

nternational Journal of Microbiology
Journal of
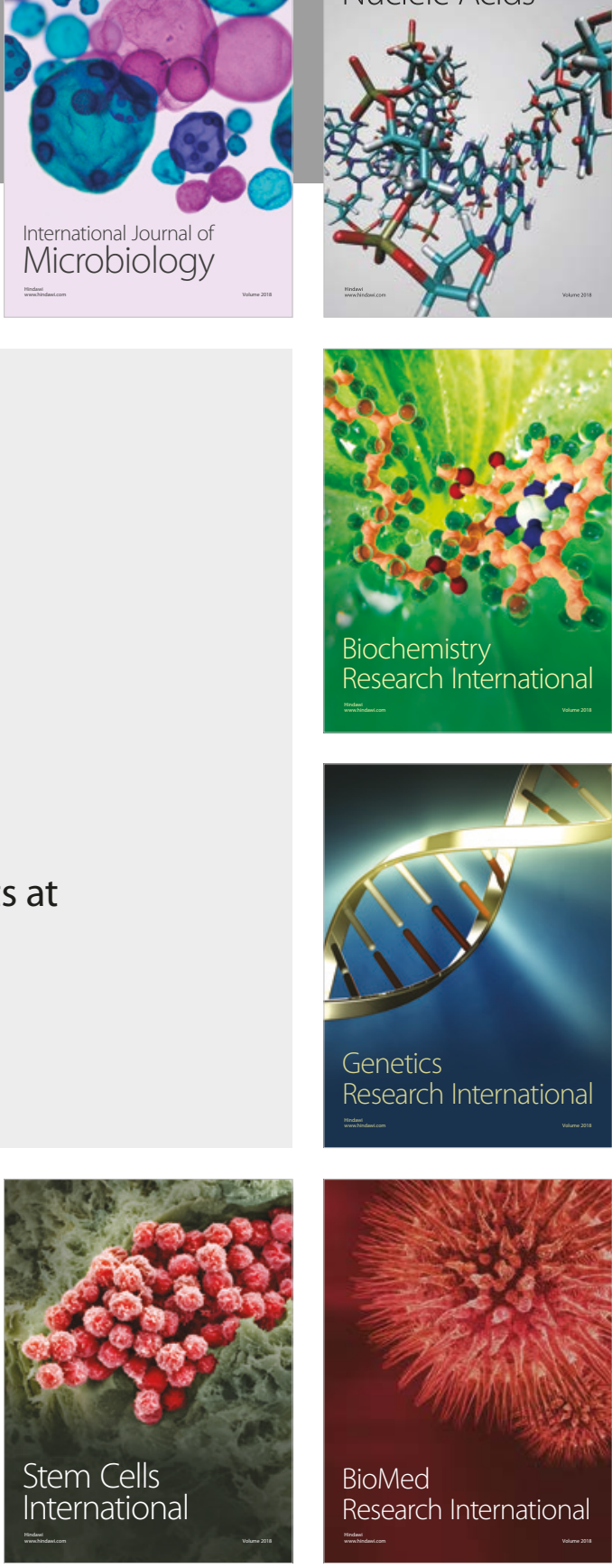
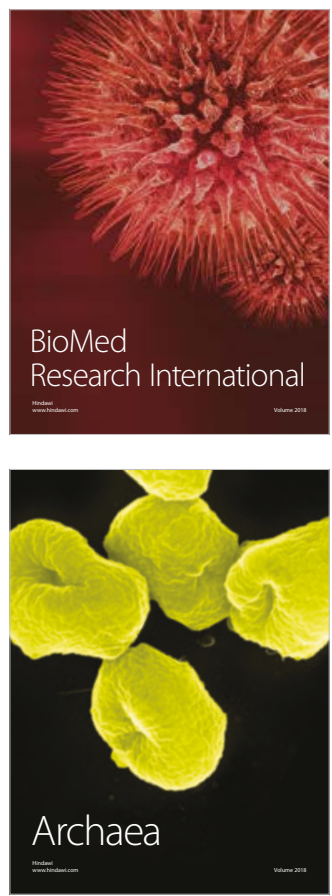